\title{
STRATEGI PENGEMBANGAN USAHA PUPUK ORGANIK PADA UD DARMA PURI FARM DI DESA TANGKAS, KECAMATAN KLUNGKUNG, KABUPATEN KLUNGKUNG
}

\author{
Organic Fertilizer Development Strategy In UD Darma Puri Farm \\ In Desa Tangkas, Sub-district of Klungkung, District of Klungkung
}

\author{
Ni Made Yuni Erawati, Ketut Suamba, Ni Wayan Sri Astiti
}

Program Studi Magister Agribisnis, Fakultas Pertanian, Universitas Udayana, Bali, Indonesia

Email: yuni_era88@ymail.com

\begin{abstract}
Fertilizer business is one of the business in agriculture proper to be developed. This can be seen from the high demand for organic fertilizer to make business people. Glance at promising business opportunities. The success of the organic fertilizer business is influenced by the strategy development . The purpose of this research is to formulate strategic alternatives and strategic priorities. Variables used in this study are the internal and external environment variables environment variables. Collection methods used were interviews, field observations, questionnaires, documentation and FGD (Focus Group Discussion) data. Data analysis methods used are SWOT Analysis and QSPM Analysis The results showed that there were four alternative strategies in the order of priority, namely (1). Trying to maintain and improve the quality of organic fertilizer. (2). Maintain old partners and explore new partnerships. (3). Improve the promotion strategy by utilizing information technology that is increasingly advanced. (4). Expand market share. The right priority strategy for marketing organic fertilizer at UD Darma Puri Farn is expanding market share which is the first choice among the four other strategies. A few things can be advised of the results of this study are as follows: (1). By utilizing media and good online marketing strategies, it is expected to increase sales without limitation of space and time. In addition, an increase in SEO (Search Engine Optimization) is also needed to make it easier for cyberspace customers to find organic fertilizer products to be marketed. (2). In order for business to develop, what must be done is increasing the means of production, efficiency, and productivity through a work system aimed at improving the production process, as well as improving the quality of human resources in the workforce through education. and training. (3). To develop a business, it needs support from all elements, not only from the internal side of the business actor but also the role of government in supporting business development. It is hoped that the government can provide its support by providing entrepreneurship education to business people through guidance and counseling to improve the ability of small businesses to become resilient and independent businesses, as well as providing business capital assistance to increase the desire of business people to develop his business.
\end{abstract}

Keywords: Strategy Development, Fertilizer Organic, SWOT, QSPM

\begin{abstract}
ABSTRAK
Bisnis pupuk adalah salah satu bisnis di bidang pertanian yang layak untuk dikembangkan. Ini bisa dilihat dari tingginya permintaan pupuk organik untuk membuat pebisnis. Sekilas peluang bisnis yang menjanjikan. Keberhasilan bisnis pupuk organik dipengaruhi oleh pengembangan strategi. Tujuan dari penelitian ini adalah untuk merumuskan alternatif strategis dan prioritas strategis. Variabel yang digunakan dalam penelitian ini adalah variabel lingkungan internal dan variabel lingkungan. Metode pengumpulan yang digunakan adalah wawancara, observasi lapangan, kuesioner, dokumentasi dan data FGD (Focus Group Discussion). Metode analisis data yang digunakan adalah Analisis SWOT dan Analisis QSPM Hasil penelitian menunjukkan bahwa ada empat strategi alternatif dalam urutan prioritas, yaitu (1). Berusaha menjaga dan meningkatkan kualitas pupuk organik. (2) Pertahankan mitra lama dan jelajahi kemitraan baru. (3) Perbaiki strategi promosi dengan memanfaatkan teknologi informasi yang semakin maju. (4) Perluas pangsa pasar. Strategi prioritas yang tepat untuk pemasaran pupuk organik di UD Darma Puri Farn adalah memperluas pangsa pasar yang merupakan pilihan pertama di antara empat strategi lainnya. Beberapa hal yang dapat disarankan dari hasil penelitian ini adalah sebagai berikut: (1). Dengan
\end{abstract}


memanfaatkan media dan strategi pemasaran online yang baik, diharapkan dapat meningkatkan penjualan tanpa batasan ruang dan waktu. Selain itu, peningkatan SEO (Search Engine Optimization) juga diperlukan untuk memudahkan pelanggan dunia maya untuk menemukan produk pupuk organik yang akan dipasarkan. (2) Agar bisnis dapat berkembang, yang harus dilakukan adalah meningkatkan sarana produksi, efisiensi, dan produktivitas melalui sistem kerja yang bertujuan untuk meningkatkan proses produksi, serta meningkatkan kualitas sumber daya manusia dalam angkatan kerja melalui pendidikan. dan pelatihan. (3) Untuk mengembangkan bisnis, diperlukan dukungan dari semua elemen, tidak hanya dari sisi internal pelaku bisnis tetapi juga peran pemerintah dalam mendukung pengembangan bisnis. Diharapkan bahwa pemerintah dapat memberikan dukungannya dengan memberikan pendidikan kewirausahaan kepada pelaku bisnis melalui bimbingan dan konseling untuk meningkatkan kemampuan usaha kecil untuk menjadi bisnis yang tangguh dan mandiri, serta memberikan bantuan modal bisnis untuk meningkatkan keinginan para pelaku bisnis untuk meningkatkan mengembangkan bisnisnya.

Kata kunci: Pengembangan Strategi, Pupuk Organik, SWOT, QSPM

\section{PENDAHULUAN}

\section{Latar Belakang}

Indonesia merupakan negara agraris. Negara yang memiliki sektor pertanian yang sangat besar. Penduduk Indonesia pada tahun 2015, sekitar 37,75 juta jiwa mata pencaharian utamanya adalah sebagai petani. Komoditas vital yang berkaitan erat dengan upaya pemenuhan kebutuhan pangan adalah pupuk. Pupuk menyumbang 20\% dari keberhasilan peningkatan produksi pertanian.

Realisasi penyaluran pupuk organik bagi petani di seluruh wilayah Bali hingga akhir Juni 2016 masih sangat rendah, yakni baru mencapai $19,06 \%$ sehingga memerlukan peningkatan pasokan pupuk organik. Tingginya permintaan pupuk organik membuat para pelaku bisnis melirik peluang bisnis yang menjanjikan tersebut. Melihat peluang tersebut banyak kalangan seperti pengusaha, produsen maupun pedagang beralih ke produk organik dengan memanfaatkan berbagai limbah untuk pembuatan pupuk organik, salah satunya adalah UD Darma Puri Farm.

Munculnya pesaing serta lingkungan bisnis yang semakin dinamis membuat sebuah bisnis harus memiliki strategi yang tepat agar dapat bersaing serta memenangkan pasar. Oleh karena itu perusahaan harus mampu merumuskan strategi yang tepat untuk menghadapi persaingan yang semakin ketat sehingga mampu bertahan dalam menghadapi industri pupuk.

Melihat kondisi tersebut maka UD Darma Puri Farm memerlukan perancangan strategi pengembangan usaha yang tepat untuk mengembangkan usahanya, agar mampu bertahan dalam persaingan yang semakin ketat dan menghadapi lingkungan yang selalu berubah.

\section{Rumusan Masalah}

Bedasarkan uraian pada latar belakang, maka dapat dirumuskan permasalahan-permasalahan sebagai berikut :

1. Apa strategi alternatif yang dapat dijalankan oleh UD Darma Puri Farm dalam pengembangan usaha pupuk organik?
2. Apa strategi prioritas yang tepat dijalankan oleh UD Darma Puri Farm dalam pengembangan usaha pupuk organik?

\section{Tujuan Penelitian}

Tujuan dari penelitian ini adalah untuk merumuskan strategi alternatif dan merumuskan strategi prioritas yang tepat dijalankan oleh UD Darma Puri Farm dalam pengembangan usaha pupuk organik.

\section{Manfaat Penelitian}

Manfaat yang diharapkan dari hasil-hasil penelitian ini adalah sebagai berikut :

1. Manfaat Praktis

Penelitian ini diharapkan dapat memberikan masukan bagi UD Darma Puri Farm bagaimana strategi yang harus dilakukan dalam memasarkan pupuk organik dan sebagai bahan pertimbangan UD Darma Puri Farm dalam pengambilan keputusan untuk menentukan strategi pengembangan usaha yang tepat agar lebih mampu berkompetisi dengan pesaingnya.

2. Manfaat Teoritis Penelitian ini diharapkan dapat menjadi media untuk menerapkan konsep-konsep teori yang selama ini diperoleh dalam perkuliahan serta meningkatkan wawasan ilmu pengetahuan khususnya penerapan ilmu manajemen strategi dibidang pemasaran

\section{KERANGKA BERPIKIR KONSEPTUAL}

Pemasaran pupuk organik Alam Asri membutuhkan ilmu manajemen untuk mencapai tujuan dengan mempertimbangkan faktor internal dan faktor eksternal yaitu dengan mengembangkan strategi dalam menyusun rencana program dan mengumpulkan informasi untuk dijadikan pertimbangan. Penentuan strategi utama dengan tiga tahapan dan kerangka kerja model analisisnya dengan matriks. Perangkat atau alat yang terbentuk matriks tersebut dapat dipakai untuk membantu para ahli strategi dalam mengidentifikasi, mengevaluasi dan memilih strategi-strategi yang paling tepat.

Tahapan pertama (input stage), yang berfungsi untuk menyampaikan informasi dasar yang 
diperlukan untuk merumuskan strategi. Tahapan kedua (matching stage), yang berfungsi untuk pengambilan strategi alternatif yang fleksibel dilakukan melalui pengembangan faktor internal dan eksternal yang utama untuk memilih dan merumuskan strategi mana yang terbaik, dan Tahap ketiga (decision stage), menggunakan analisis QSPM (Quantitative Strategics Planning Matrix) yang bertujuan untuk menetapkan ketertarikan relative (relative attractiveness) dari strategi-strategi yang bervariasi yang telah dipilih dengan total score attractiveness tertinggi untuk menentukan strategi yang paling baik sebagai strategi prioritas yang diimplementasikan pada pengembangan pemasaran pupuk organik Alam Asri.

\section{METODE PENELITIAN}

\section{Lokasi Penelitian}

Penelitian dilakukan pada perusahaan pupuk organik UD Darma Puri Farm di Desa Tangkas, Kecamatan Klungkung, Kabupaten Klungkung, Provinsi Bali. Lokasi penelitian ini dilakukan dengan metode purposive yaitu metode penentuan lokasi penelitian secara sengaja dengan pertimbangan antara lain : UD Darma Puri Farm merupakan perusahaan pupuk organik yang bekerja sama dengan Pemerintah Provinsi Bali sebagai asosiasi penyaluran pupuk bersubsidi di Kabupaten Klungkung dan menurut pemilik perusahaan, belum pernah dilakukan penelitian tentang STRATEGI PENGEMBANGAN USAHA pada UD Darma Puri Farm, Kecamatan Klungkung, Kabupaten Klungkung.

\section{Metode Pengumpulan Data}

Metode pengumpulan data menggunakan tiga metode yaitu sebagai berikut.

1. Wawancara terstruktur, yaitu merupakan teknik pengumpulan data dimana pewawancara (peneliti) dalam mengumpulkan data mengajukan suatu pertanyaan kepada yang diwawancarai (Sugiyono, 2014).

2. Observasi lapangan, yaitu mengadakan pengamatan secara langsung terhadap obyek yang diteliti yaitu bagaimana kegiatan perusahaan dalam melaksanakan aktivitas pemasaran.

3. Angket dengan cara menyebarkan kuesioner diisi oleh responden yang dalam hal ini pihak manajemen terutama yang berkaitan dengan pemberian skor dan rating pada matriks IFE, EFE, matriks Internal dan Eksternal (I -E Matrix), analisis SWOT, SPACE matriks dan matriks QSPM, contoh kuesioner terlampir.

4. Dokumentasi dilakukan dengan meneliti dokumen-dokumen yang ada dengan cara mengambil data sekunder dari catatan atau buku, serta dokumen-dokumen untuk memperoleh data seperti gambaran umum perusahaan, laporan penjualan perusahaan dan foto-foto kegiatan di perusahaan.
5. FGD (Focus Group), yaitu teknik pengumpulan data yang umumnya dilakukan pada penelitian kualitatif dengan tujuan menemukan makna sebuah tema menurut pemahaman sebuah kelompok.

\section{Variabel Penelitian}

\section{Pengukuran variabel penelitian}

Pengukuran variabel penelitian ini dilakukan berdasarkan indikator dan parameter. Variabel yang digunakan dalam penelitian strategi pengembangan usaha pupuk organik ini diklasifikasikan menjadi variabel lingkungan internal dan variabel lingkungan ekternal.

1. Variabel lingkungan internal

Lingkungan internal perusahaan sebagai suatu proses dengan mana perencana strategi mengkaji pemasaran, dan distribusi perusahaan, penelitian dan pengembangan, produksi dan operasi, sumber daya dan karyawan perusahaan, serta faktor keuangan dan akuntansi untuk menentukan dimana perusahaan mempunyai kekuatan dan kelemahan yang penting sehingga perusahaan dapat memanfaatkan peluang dengan cara yang paling efektif dan dapat menangani ancaman di dalam lingkungan.

2. Variabel lingkungan eksternal

Lingkungan external meliputi variabel-variabel di luar organisasi yang dapat berupa tekanan umum dan tren di dalam lingkungan ataupun faktor-faktor spesifik yang beroperasi dalam lingkungan kerja. Variabel-variabel ini terbagi menjadi dua jenis, yaitu ancaman dan peluang, dimana memerlukan pengendalian jangka panjang dari manajemen puncak organisasi.

\section{Batasan operasional variabel}

Definisi operasional variabel lingkungan internal dan variabel lingkungan eksternal terikat dengan indikatornya masing-masing yang dimaksudkan dalam penelitian ini adalah sebagai berikut :

1. Variabel lingkungan internal merupakan lingkungan yang berada di dalam perusahaan yang mewakili kekuatan dan kelemahan yang dapat dikendalikan oleh manajemen UD Darma Puri Farm.

2. Variabel lingkungan eksternal merupakan lingkungan yang berada di luar perusahaan, mewakili peluang yang perlu segera mendapat perhatian dan secara bersamaan untuk mencegah ancaman yang datang dan segera diantisipasi oleh UD Darma Puri Farm.

\section{Metode Analisis Data}

Metode pengolahan dan analisis data yang digunakan dalam penelitian ini adalah analisis lingkungan internal dan eksternal pemasaran. Pada Tahap Pemasukkan (The Input Stage) digunakan matriks IFE (Internal Factor Evaluation) dan EFE (External Factor Evaluation). 
Dalam Tahap Pemaduan (The Matching Stage) digunakan alat analisis Matriks IE dan Matriks SWOT. Matriks IE digunakan untuk menentukan posisi usaha. Matriks SWOT digunakan untuk menghasilkan strategi-strategi yang sesuai dengan kondisi internal dan eksternal pemasaran perusahaan.

Tahap terakhir adalah Tahap Keputusan (The Decision Stage). Matriks SPACE (Strategic Position and Action ), mengindikasikan apakah strategi yang agresif, konservatif, defensif, atau kompetitif yang paling cocok dengan perusahaan tertentu. Matriks QSPM digunakan dalam penentuan prioritas dari beberapa alternatif
STRATEGI PENGEMBANGAN USAHA yang dihasilkan dari Tahap Pemaduan.

\section{GAMBARAN UMUM PERUSAHAAN}

\section{Sejarah Singkat Perusahaan}

UD. Darma Puri Farm adalah Usaha Perseorangan yang dirintis oleh I Ketut Darmawan S.Pt. Didirikan pada Bulan Maret 2007 dan secara legalitas berdiri pada tanggal 12 Pebruari 2012 dengan dokumen SIUP dan TDP. Usaha ini fokus penyediaan sarana prasarana peternakan dan pertanian, produksi massal pupuk organik "Alam Asri”, suplier produk makanan sehat dan sebagai konsultan bidang pertanian peternakan.

\section{Struktur Organisasi}

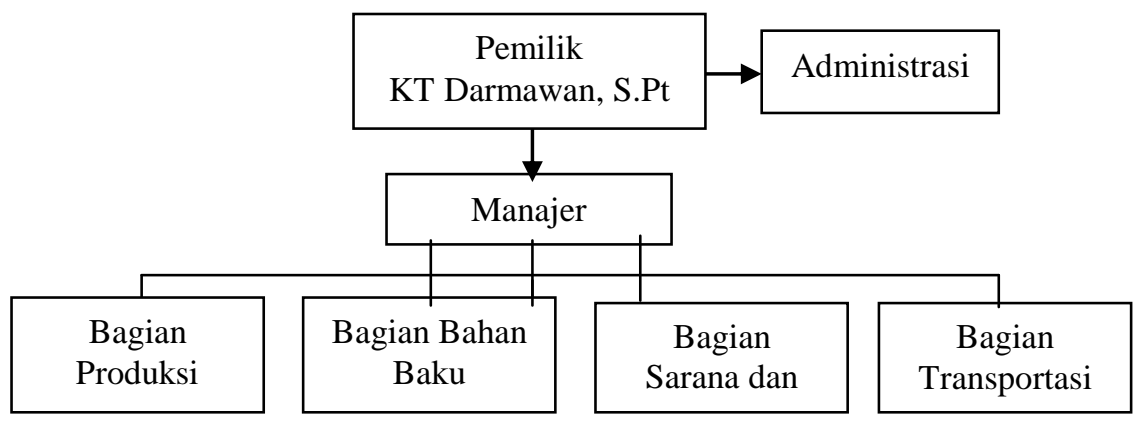

Gambar 1. Struktur Organisasi UD Darma Puri Farm Sumber. UD Darma Puri Farm

\section{Produksi}

Proses produksi yang dilalui dalam memproduksi pupuk organik memerlukan bahan baku dan alat-alat sebagai berikut : (1) Kebutuhan bahan baku dibeli dari peternak maupun kelompok ternak sapi yang ada di daerah Kabupaten Klungkung, Gianyar dan Karangasem, serta sebagian besar diperoleh dari simantri-simantri yang ada di Kabupaten Klungkung dan Kabupaten Karangasem. (2) Peralatan yang digunakan dalam kegiatan pembuatan pupuk organik adalah menggunakan cluser atau mesin pencacah untuk penggilingan kotoran padat sapi yang sudah dijemur, setelah itu disaring menggunakan pengayak. Ember digunakan untuk mencampur mikroba aktif atau mol dengan air, setelah itu disemprot ke kotoran padat sapi dengan menggunakan sprayer. Terpal digunakan untuk alas dan menutup kotoran padat sapi pada saat proses fermentasi berlangsung. Cangkul dan sekop untuk membolak-balikan pupuk. Selanjutnya dalam proses pengemasan digunakan mesin jahit.

Adapun urutan dari proses produksinya dapat dijelaskan sebagai berikut :

1). Penjemuran

Kotoran padat ternak yang sudah dikumpulkan pada suatu tempat akan dijemur dan dikeringkan terlebih dahulu sebelum digiling dan diayak. Hal ini bertujuan untuk mengurangi kadar air yang ada pada bahan untuk pupuk sampai kadar air yang terkandung menjadi sekitar $15-20 \%$. Waktu penjemuran tergantung dari cuaca, jika musim kemarau maka waktu yang dibutuhan hanya sebentar saja dan sebaliknya jika musim hujan maka waktu yang dibutuhkan lebih lama.

2). Penggilingan dan pengayakan

Penggilingan pada kotoran padat ternak dilakukan untuk melumatkan kotoran yang padat menjadi hancur berupa serbuk. Setelah proses penggilingan maka proses pengayakan dilakukan untuk memisahkan sampah dan bahan yang tidak bisa difermentasi seperti plastik, batang kayu dari pakan dan lain-lainnya sehingga mendapatkan pupuk organik yang bersih.

3). Melarutkan aktivator/decomposer yang akan disiramkan ke kotoran ternak

Mikroba aktif atau dekomposer yang biasa digunakan oleh UD Darma Puri Farm adalah EM-4. Cara melarutkan activator/decomposer adalah dengan mencampurkan larutan EM4 dan molase/gula dengan air, dengan perbandingan $1: 1$ : 100, yang kemudian sudah didiamkan selama 3 hari sebelumnya untuk dipergunakan agar terjadi proses fermentasi. Larutan yang sudah aktif tersebut dapat disemprotkan pada limbah ternak dengan kapasitas limbah 1 ton.

\section{4). Pemeraman}

Setelah bahan untuk pupuk diayak maka setelah itu dicampur dengan kapur atau dolomit terlebih dahulu. Fungsi kapur sangat bermanfaat bagi tanah 
dan tanaman yaitu untuk memberikan nutrisi yang berharga bagi tanaman dan membantu mengubah $\mathrm{pH}$ tanah sesuai dengan kebutuhan tanaman. 1 ton kotoran padat dicampur dengan kapur sebanyak 20 $\mathrm{kg}$.

Setelah pencampuran maka kotoran yang sudah dicampur dengan kapur selanjutnya akan difermentasi menggunakan mikroba aktif dan Molase yang sudah jadi. Setelah itu kotoran ditutup dengan terpal dan diperam beberapa hari. Proses pemeraman sampai 21 hari. Setelah beberapa hari suhu kotoran padat yang sudah difermentasi akan naik yang menandakan bahwa bakteri sedang bekerja. Setiap 5 hari sekali kotoran padat diaduk untuk mengurangi panas. Setelah 21 hari pendinginan dilanjutkan dengan penghamparan sampai pupuk benar-benar agak kering dengan kadar air sampai $30 \%$.

\section{5). Penimbangan dan pengemasan}

Pupuk yang sudah dingin setelah itu ditimbang dan dikemas terlebih dahulu ke dalam kemasan berupa karung isian $25 \mathrm{~kg}, 35 \mathrm{~kg}$ dan $40 \mathrm{~kg}$, setelah dikemas lalu dijahit.

\section{Saluran Distribusi}

Pemasaran pupuk yang dilakukan UD Darma Puri Farm baru hanya bisa memenuhi kebutuhan pupuk di Kabupaten Klungkung, Karangasem dan Bangli. Saluran yang digunakan oleh UD Darma Puri Farm untuk memasarkan pupuk organiknya yaitu produsen memilih agen sebagai penyalurnya dan produsen juga sebagai penyalur langsung ke konsumen. Alat transportasi yang digunakan untuk mendistribusikan pupuk ialah dengan menggunakan pick up dan truck.

\section{HASIL DAN PEMBAHASAN}

\section{Identifikasi Faktor Internal Dan Eksternal}

\section{Identifikasi faktor internal}

Berdasarkan faktor internal dapat diidentifikasikan kekuatan dan kelemahan perusahaan. Adapun faktor internal tersebut sebagai berikut :

1. Kekuatan (Strength)

a. Kualitas produk yang baik

Pupuk organik "Alam Asri" memiliki kualitas yang baik karena sudah dilaksanakan uji kualitas pupuk di Laboratorium Ilmu Tanah Universitas Udayana. Jaminan terhadap uji kualitas pupuk organik terhadap produksi tanaman sangat diperlukan untuk melindungi konsumen serta menggalang kepercayaan terhadap produsen pupuk. Sampai sekarang UD Darma Puri Farm tetap berusaha mempertahankan kualitas produknya untuk menjaga kepuasan pelanggan.

b. Lokasi perusahaan strategis

Lokasi yang strategis adalah wilayah penempatan operasi produksi sebuah perusahaan yang dapat memberikan keuntungan maksimal terhadap perusahaan tersebut, karena tujuan strategi lokasi adalah untuk memaksimalkan keuntungan lokasi bagi perusahaan. Lokasi UD Darma Puri Farm terletak dekat dengan Jalan Raya Prof. Dr. Ida Bagus Mantra yaitu merupakan salah satu ruas Jalan Nasional di Bali, yang memiliki fungsi strategis dalam menghubungkan lalu lintas antar kabupaten terutama wilayah Bali Timur. Letak lokasi UD Darma Puri Farm yang strategis karena dekat jalan nasional sangat memudahkan mobilitas penduduk di kawasan tersebut untuk sampai ke lokasi.

c. Harga terjangkau sesuai dengan kualitas produk

Harga seringkali dikaitkan dengan kualitas, pelanggan cenderung untuk menggunakan harga sebagai indikator kualitas atau kepuasan potensial dari suatu produk. Dilihat dari kualitas yang dimiliki oleh pupuk organik "Alam Asri" yang sudah teruji, maka harga yang diberikan sudah sesuai dengan harga yang pantas untuk konsumen langsung yaitu Rp. $1.000,00$ per kilogram.

d. Sarana dan prasarana memadai

Sarana yang dimiliki oleh UD Darma Puri Farm yaitu mesin-mesin produksi seperti mesin jahit, mesin pencacah, mesin pengayak, jetpump dan transportasi berupa pick up dan truck. Sedangkan untuk prasarana yang dimiliki oleh perusahaan adalah kantor, gudang dan kebun. Sarana dan prasarana yang dimiliki oleh UD Darma Puri Farm sudah terbilang memadai untuk memenuhi aktivitas kegiatan produksi maupun pemasaran produk.

e. Intensifnya pembinaan kelompok-kelompok ternak melalui dinas terkait

Perlunya upaya pembinaan kepada kelompok-kelompok ternak dalam rangka penyediaan pupuk. Melalui pembinaan, pendampingan, penyuluhan dan bimbingan teknis, serta adanya fasilitas bantuan pada kelompok-kelompok ternak diharapkan saling bersinergi, sehingga meningkatkan kerjasama yang baik dalam kegiatan memproduksi pupuk organik.

\section{Kelemahan (Weaknesses)}

a. Jaringan pemasaran masih terbatas UD Darma Puri Farm belum menjangkau daerah pemasaran secara menyeluruh. Aktivitas pemasaran pada perusahaan belum optimal sehingga jaringan pemasarannya masih terbatas.

b. Proses pengolahan bahan baku yang lambat Proses pengolahan bahan baku tergantung dari cuaca sehingga jika proses pengolahan mengalami keterlambatan disebabkan karena cuaca yang tidak menentu seperti penjemuran kotoran padat memakan waktu lebih lama untuk kering karena hujan yang terus-menerus.

c. Kegiatan promosi kurang 
Kegiatan promosi yang dilakukan oleh UD Darma Puri Farm adalah dengan memasang spanduk atau banner, brosur dan via website. Aktivitas promosi seperti iklan di media elektronik, antara lain iklan di radio, televisi, toko online dan iklan yang ada di media cetak seperti majalah atau koran belum dilakukan.

d. Rendahnya pengetahuan SDM

Pengetahuan pekerja pada UD Darma Puri Farm masih terbilang rendah. Hal ini bisa dilihat dari kurangnya penguasaan IPTEK dan keterampilan dalam bidang pekerjaanya.

e. Persediaan bahan baku yang tidak menentu UD Darma Puri Farm belum bisa memenuhi persediaan kebutuhan bahan baku sendiri seperti kotoran ternak sapi karena tersedianya bahan baku yang tidak menentu dan tergantung dari peternak apakah bisa menyediakan bahan baku berapapun yang diperlukan nantinya.

\section{Identifikasi faktor ekternal}

Berdasarkan faktor eksternal dapat diidentifikasikan peluang dan ancaman perusahaan. Adapun faktor eksternal tersebut sebagai berikut :

1. Peluang (Opportunities)

a. Daya beli konsumen meningkat

Trend masyarakat untuk kembali ke alam (Back To Nature) telah menyebabkan permintaan produk pertanian organik meningkat. Meningkatnya daya beli masyarakat akan pupuk organik menjadi peluang untuk UD Darma Puri Farm dalam memasarkan produknya sehingga akan meningkatkan keuntungan perusahaan.

b. Pola berfikir masyarakat (konsumen) semakin maju

Peradaban yang semakin modern membuat masyarakat mulai sadar akan bahaya yang timbul akibat dari pemakaian bahan kimia yang digunakan dalam pertanian. Kini masyarakat lebih arif dalam memilih produk pertanian yang ramah lingkugan dan bebas dari kimia. Berubahnya pola pikir masyarakat yang semakin maju mengenai produk pertanian organik akan memberikan peluang kepada perusahaan karena akan meningkatkan permintaan pupuk organik.

c. Perkembangan teknologi komunikasi mendukung

Perkembangan teknologi komunikasi yang semakin canggih memberikan peluang untuk terus meningkatkan kualitas serta mencapai tujuan perusahaan. Dengan teknologi komunikasi yang mendukung maka memudahkan UD Darma Puri Farm dalam memasarkan produknya. Perusahaan sudah menggunakan jasa internet berupa website dan email dalam memasarkan produknya.

d. Trend gaya hidup sehat Seiring dengan semakin berkembangnya "trend" gaya hidup sehat menyebabkan masyarakat kini lebih suka mengonsumsi produk organik ketimbang yang menggunakan bahan an-organik sehingga permintaan akan produk pertanian organik dan ramah lingkungan semakin meningkat. Melihat fenomena seperti ini akan menjadikan peluang yang bagus untuk UD Darma Puri Farm dalam memasarkan produknya.

e. Persepsi konsumen terhadap merek tinggi Konsumen disajikan dengan berbagai produk pupuk organik untuk memilih dari dalam pasar saat ini. Merek merupakan salah satu faktor yang mempengaruhi keputusan konsumen untuk membeli. Pupuk organik bermerek Alam Asri merupakan pupuk organik yang diproduksi oleh UD Darma Puri Farm, dimana perusahaan sudah memiliki Surat Izin Usaha Perdagangan (SIUP), Tanda Daftar Perusahaan (TDP) dan produk sudah melaksanakan uji kualitas yang kandungan unsur haranya sesuai dengan anjuran pemerintah. Namun, apabila ijin sudah diperoleh maka standar mutu dari pupuk organik "Alam Asri" sudah tidak diragukan lagi sehingga membuka peluang perusahaan dalam memasarkan produknya.

\section{b. Ancaman (Threats)}

a. Perusahaan pesaing

Bisnis pertanian organik memang dari waktu ke waktu sangat diminati oleh banyak orang salah satunya usaha pupuk organik. UD Darma Puri Farm merupakan salah satu perusahaan yang memasarkan pupuk organik dan secara sudah berdiri sejak tahun 2007 namun secara legalitas berdiri pada tahun 2012. Seiring berkembangnya waktu maka pesaingpun mulai bermunculan seperti Bokhasi Kotaku produksi PT Songgolangit Persada, Bali Organikultur produksi PT. Wedhatama Sukses Makmur, Pupuk Tanah Subur Super produksi Agung di Singapadu, Pubotan produksi UD Setiawan dan pesaing lainnya.

b. Naiknya biaya produksi

Naiknya biaya produksi seperti naiknya biaya bahan baku, biaya tenaga kerja dan biaya overhead pabrik akan merugikan perusahaan. Misalkan saja terjadi kenaikan harga BBM akan berpengaruh bagi semua aspek perekonomian. Bagi perusahaan, dampak kenaikan BBM akan mempengaruhi seluruh kegiatan operasi. Apabila harga produk dinaikkan terlalu mahal maka akan mengurangi penjualan yang ditargetkan karena konsumen kini akan lebih mengurangi jumlah konsumsinya.

c. Ketersediaan tenaga kerja sedikit

Sedikitnya tenaga kerja yang berminat dalam kegiatan penjemuran, pengolahan dan pengemasan dalam pekerjaan mengolah pupuk organik sehingga akan mengakibatkan proses produksi nantinya terhambat.

d. Faktor cuaca yang tidak menentu Faktor cuaca sangat mempengaruhi aktivitas kegiatan produksi terutama bagi produsen 
pupuk organik. Bagi produsen pupuk organik, turunnya hujan menyebabkan produksi terhambat. Kotoran ternak yang masih basah akan membutuhkan waktu lebih lama untuk dikeringkan.

e. Posisi tawar konsumen semakin tinggi Semakin tinggi daya tawar pembeli dalam menuntut harga yang lebih rendah ataupun kualitas produk yang lebih tinggi, semakin rendah profit atau laba yang akan didapatkan oleh perusahaan produsen. Harga produk yang lebih rendah berarti pendapatan bagi perusahaan juga semakin rendah. Di satu sisi, Perusahaan memerlukan biaya yang tinggi dalam menghasilkan produk yang berkualitas tinggi.

\section{Penetapan Alternatif Strategi}

\section{Analisis matriks IFE}

Dalam analisis internal matriks IFE dilakukan pengidentifikasian faktor-faktor strategis internal yang memiliki pengaruh terhadap strategi pengembangan usaha pupuk organik pada UD Darma Puri Farm yang terdiri dari kekuatan (strengths) dan kelemahan (weakness). Dalam analisis tersebut dilakukan pembobotan dan pemberian rating terhadap faktor-faktor strategis internal UD Darma Puri Farm. Perhitungan rata-rata pembobotan faktor-faktor strategis internal dapat dilihat pada Tabel 6.1.

Tabel 1. Analisis Matriks IFE UD Darma Puri Farm

\begin{tabular}{lccc}
\hline \multicolumn{1}{c}{$\begin{array}{c}\text { Faktor Internal } \\
(1)\end{array}$} & $\begin{array}{c}\text { Bobot } \\
(2)\end{array}$ & $\begin{array}{c}\text { Rating } \\
(3)\end{array}$ & $\begin{array}{c}\text { Skor } \\
(4)\end{array}$ \\
\hline Kekuatan & 0,15 & 4 & 0,60 \\
- Kualitas produk yang baik & 0,10 & 3 & 0,30 \\
- Lokasi perusahaan strategis & 0,10 & 4 & 0,40 \\
- Harga terjangkau sesuai dengan kualitas produk & 0,10 & 3 & 0,30 \\
- Sarana dan prasarana memadai & & & 0,40 \\
- Intensifnya pembinaan kelompok-kelompok ternak melalui dinas & 0,10 & 4 & 2,00 \\
$\quad$ terkait & & & 0,20 \\
Jumlah Variabel Kekuatan & & & 0,20 \\
Kelemahan & 0,10 & 2 & 0,20 \\
- Jaringan pemasaran masih terbatas & 0,10 & 2 & 0,10 \\
- Proses pengolahan bahan baku yang lambat & 0,10 & 2 & 0,10 \\
- Kegiatan promosi kurang & 0,05 & 2 & 0,80 \\
- Pendahnya pengetahuan SDM $\quad$ Persediaan bahan baku yang tidak menentu & 0,10 & 1 & 2,80 \\
Jumlah Variabel Kelemahan & & & 1,20 \\
Total Skor & 1.00 & & \\
Selisih Skor & & & \\
\hline
\end{tabular}

Selisih Skor

Berdasarkan Tabel 1 diperoleh informasi bahwa total skor berdasarkan matriks IFE pada perusahaan sebesar 2,80 dan nilai ini melebihi kriteria yang ditetapkan yaitu 2,50. Hal ini menunjukkan bahwa perusahaan mempunyai kemampuan untuk mengantisipasi kelemahan internal yang ada. Kekuatan utama pada UD Darma Puri Farm adalah kualitas produk yang baik dengan nilai skor yang paling tinggi yakni 0,60 . Produk pupuk organik "Alam Asri" merupakan pupuk yang diolah ditangani secara baik dan memiliki banyak manfaat bagi pertumbuhan tanaman salah satunya meningkatkan produktivitas dari lahan pertanian. Pupuk ini telah teruji klinis laboratorium dan teruji pula secara lapangan sehingga sudah dipastikan memiliki kualitas yang baik. Sedangkan kelemahan utama yang dimiliki oleh UD Darma Puri Farm adalah jaringan pemasaran masih terbatas, proses pengolahan bahan baku yang lambat dan kegiatan promosi yang masih kurang dengan masing-masing nilai skor yang paling tinggi yakni 0,20 . Jaringan pemasaran masih terbatas karena untuk penyaluran pupuk organik " Alam Asri” masih seputaran Kabupaten Klungkung, Bangli dan Karangasem. Penyebaran informasi mengenai produk pupuk organik "Alam Asri" juga dirasa masih kurang dibandingkan dengan promosi yang dilakukan oleh pesaing-pesaingnya.

\section{Analisis matriks EFE}

Dalam analisis eksternal matriks EFE dilakukan pengidentifikasian faktor-faktor strategis eksternal yang memiliki pengaruh terhadap STRATEGI PENGEMBANGAN USAHA pupuk organik pada UD Darma Puri Farm yang terdiri dari peluang (opportunities) dan ancaman (threats). Dalam analisis tersebut dilakukan pembobotan dan pemberian rating terhadap faktor-faktor strategis eksternal UD Darma Puri Farm. Perhitungan ratarata pembobotan faktor-faktor strategis eksternal dapat dilihat pada Tabel 2. 
Tabel 2. Analisis Matriks EFE UD Darma Puri Farm

\begin{tabular}{lccc}
\hline \multicolumn{1}{c}{ Faktor Eksternal } & Bobot & Rating & Skor \\
\hline Peluang & & & \\
- Daya beli konsumen meningkat & 0,15 & 4 & 0,60 \\
- Pola berfikir masyarakat (konsumen) semakin maju & 0,10 & 3 & 0,30 \\
- Perkembangan teknologi komunikasi mendukung & 0,10 & 3 & 0,30 \\
- Trend gaya hidup sehat & 0,10 & 3 & 0,30 \\
- Persepsi konsumen terhadap merek tinggi & 0,10 & 4 & 0,40 \\
Jumlah Variabel Peluang & & & 1,90 \\
Ancaman & & & \\
- Perusahaan pesaing & 0,10 & 2 & 0,20 \\
- Naiknya biaya produksi & 0,10 & 2 & 0,20 \\
- Ketersediaan tenaga kerja sedikit & 0,10 & 2 & 0,20 \\
- Faktor cuaca yang tidak menentu & 0,05 & 2 & 0,10 \\
- Posisi tawar konsumen semakin tinggi & 0,10 & 2 & 0,20 \\
Jumlah Variabel Ancaman & & & 0,90 \\
Total Skor & 1.00 & & 2,80 \\
Selisih Skor & & & 1,00 \\
\hline
\end{tabular}

Sumber : Analisis Data Primer Hasil Penelitian (2017)

Berdasarkan Tabel 2 diperoleh informasi bahwa total skor berdasarkan matriks EFE pada perusahaan sebesar 2,80 yang artinya bahwa perusahaan mampu untuk mengantisipasi ancaman eksternal yang ada dan memanfaatkan peluang yang ada. Peluang utama UD Darma Puri Farm terdapat pada faktor daya beli konsumen meningkat dengan skor paling tinggi yakni 0,60. Jika Daya beli konsumen meningkat terhadap produk pupuk organik maka akan meningkatkan jumlah permintaan pada produk pupuk organik dan diharapkan nantinya membuat usaha pemasaran pupuk organik ini semakin berkembang sehingga saat pasar terbuka akan membuat usaha ini semakin membentang luas. Sedangkan ancaman utama pada UD Darma Puri Farm adalah faktor perusahaan pesaing, naiknya biaya produksi, Ketersediaan tenaga kerja sedikit dan posisi tawar konsumen semakin tinggi dengan nilai skor masing-masing 0,20. Naiknya biaya produksi bisa mengakibatkan harga produk ikut naik. Naiknya harga produk dan posisi tawar konsumen yang semakin tinggi akan mengakibatkan konsumen akan mencari produk yang lebih murah dan akan lari ke penjual lainnya (pesaing).

Analisis Matriks Internal dan Eksternal (I - E Matrix)

Berdasarakan Matriks IE dimana terdapat dua dimensi kunci, yaitu total nilai IFE yang diberi bobot pada sumbu-X dan total nilai EFE yang diberi bobot pada sumbu-Y. Pada sumbu-X matriks IE, skor total IFE adalah 2,80 yang menunjukkan posisi internal rata-rata. Demikian pula pada sumbu-y matriks IE, skor total EFE adalah 2,80 yang menunjukkan posisi eksternal menengah. Matriks IE ditunjukkan pada Gambar 2.

\section{TOTAL INT ERNAL}

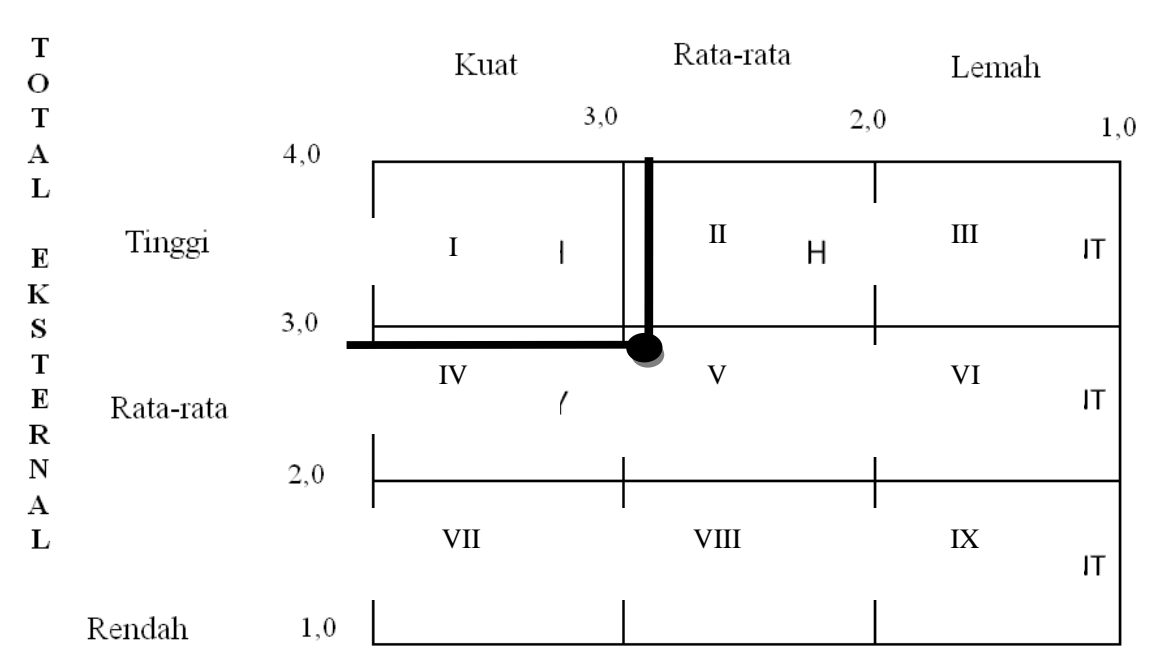

Gambar 2. Matriks Internal-Eksternal (IE) UD Darma Puri Farm 
Hasil pemetaan matriks IE di atas, menunjukkan bahwa UD Darma Puri Farm berada pada sel V. Hasil pembobotan terletak pada sel V, jadi strategi yang layak digunakan adalah strategi penetrasi pasar dan perkembangan produk dalam memasarkan produk pupuk organik.

Strategi penetrasi pasar merupakan usaha perusahaan untuk meningkatkan penjualan atas produk dan pasar yang telah tersedia melalui usahausaha pemasaran yang lebih agresif. Penetrasi pasar berusaha untuk meningkatkan pangsa pasar bagi produk ataupun pelayanan yang ada sekarang pada pasar yang tersedia melalui usaha-usaha pemasaran yang lebih besar yang dapat dilakukan dengan promosi melalui media internet, surat kabar, dan radio. Strategi pengembangan produk merupakan suatu strategi agar perusahaan dapat meningkatkan penjualan dengan cara meningkatkan atau memodifikasi desain dari penampilan produk atau jasa yang ada sekarang.

\section{Analisis SWOT}

Berdasarkan analisis matrik strategi internal dan eksternal didapatkan nilai kekuatan 2,00, kelemahan 0,80 , peluang 1,90 dan ancaman 0,90 . Besarnya nilai faktor internal dan eksternal digunakan untuk pertimbangan dalam merumuskan strategi yang ideal. Kombinasi dari faktor internal dan eksternal ini menghasilkan 4 alternatif strategi yaitu: 1). Strategi S-O yaitu strategi pengembangan usaha dengan menggunakan kekuatan yang dimiliki untuk memanfaatkan peluang yang ada; 2). Strategi W-O yaitu strategi pengembangan usaha dengan mengambil keuntungan dari peluang untuk mengatasi kelemahan yang dimiliki; 3). Strategi S-T yaitu strategi pengembangan usaha dengan menggunakan kekuatan untuk menghindari ancaman; 4). Strategi W-T yaitu strategi pengembangan usaha dengan meminimalkan kelemahan dengan menghindari ancaman. Matriks SWOT dapat dilihat pada Tabel 3.

Tabel 3. Matriks Strategi Alternatif dengan Analisis SWOT UD Darma Puri Farm

\begin{tabular}{|c|c|c|}
\hline EFE & $\begin{array}{l}\text { Kekuatan }(S) \\
\text { 1. Kualitas produk yang baik }(0,60) \\
\text { 2. Lokasi perusahaan strategis }(0,30) \\
\text { 3. Harga terjangkau sesuai dengan } \\
\text { kualitas produk }(0,40) \\
\text { 4. Sarana dan prasarana memadai } \\
(0,30) \\
\text { 5. Intensifnya pembinaan kelompok- } \\
\text { kelompok ternak melalui dinas } \\
\text { terkait }(0,40)\end{array}$ & $\begin{array}{l}\text { Kelemahan }(\mathrm{W}) \\
\text { 1. Jaringan pemasaran masih } \\
\text { terbatas }(0,20) \\
\text { 2. Proses pengolahan bahan baku } \\
\text { yang lambat }(0,20) \\
\text { 3. Kegiatan promosi kurang } \\
(0,20) \\
\text { 4. Rendahnya pengetahuan SDM } \\
(0,10) \\
\text { 5. Persediaan bahan baku yang } \\
\text { tidak menentu }(0,10)\end{array}$ \\
\hline $\begin{array}{l}\text { Peluang }(\mathrm{O}) \\
\text { 1. } \begin{array}{l}\text { Daya beli konsumen } \\
\text { meningkat }(0,60)\end{array} \\
\text { 2. } \begin{array}{l}\text { Pola berfikir masyarakat } \\
\text { (konsumen) semakin maju }\end{array} \\
\begin{array}{l}(0,30) \\
\text { 3. }\end{array} \text { Perkembangan teknologi } \\
\text { komunikasi mendukung } \\
(0,30) \\
\text { 4. } \begin{array}{l}\text { Trend gaya hidup sehat } \\
(0,30)\end{array} \\
\text { 5. } \begin{array}{l}\text { Persepsi konsumen terhadap } \\
\text { merek tinggi }(0,40)\end{array}\end{array}$ & $\begin{array}{l}\text { STRATEGI SO } \\
\text { 1. Berusaha mempertahankan dan } \\
\text { meningkatkan kualitas pupuk } \\
\text { organik }(\mathrm{S} 1+\mathrm{S} 3+\mathrm{S} 5+\mathrm{O} 1+05)\end{array}$ & $\begin{array}{l}\text { STRATEGI WO } \\
\text { 1. Memperbaiki dan } \\
\text { meningkatkan strategi } \\
\text { promosi dengan teknologi } \\
\text { informasi yang semakin maju } \\
(\mathrm{W} 1+\mathrm{W} 3+\mathrm{O} 1+02+\mathrm{O} 3+ \\
04+05)\end{array}$ \\
\hline $\begin{array}{l}\text { Ancaman }(\mathrm{T}) \\
\text { 1. Perusahaan pesaing }(0,20) \\
\text { 2. Naiknya biaya produksi } \\
(0,20) \\
\text { 3. Ketersediaan tenaga kerja } \\
\text { sedikit }(0,20) \\
\text { 4. Faktor cuaca yang tidak } \\
\text { menentu }(0,10) \\
\text { 5. Posisi tawar konsumen } \\
\text { semakin tinggi }(0,20)\end{array}$ & $\begin{array}{l}\text { STRATEGI ST } \\
\text { 1. Mempertahankan mitra yang lama } \\
\text { dan menjajaki kemitraan yang baru } \\
(\mathrm{S} 1+\mathrm{S} 2+\mathrm{S} 4+\mathrm{O} 3+\mathrm{O} 4)\end{array}$ & $\begin{array}{l}\text { STRATEGI WT } \\
\text { 1. Memperluas pangsa } \\
(\mathrm{W} 1+\mathrm{T} 1)\end{array}$ \\
\hline
\end{tabular}

Sumber : Analisis Data Primer Hasil Penelitian (2017)

Dari hasil matrik SWOT yang didapatkan maka dapat disimpulkan bahwa terdapat sembilan strategi alternatif yang dapat dijabarkan sebagai berikut :
1. Berusaha mempertahankan dan meningkatkan kualitas pupuk organik.

Kualitas pupuk organik harus bisa dijaga sebelum dipasarkan agar tidak menimbulkan 
kekecewaan konsumen karena produknya tidak bermutu. Menjaga kualitas produk bisa menekan biaya dan menambah kualifikasi perusahaan kita bila mau memulai kerja sama baru. Meningkatnya kualitas produk akan menimbulkan permintaan yang meningkat terhadap produk itu sendiri.

2. Mempertahankan mitra yang alam dan menjajaki kemitraan yang baru

Kerjasama selama ini yang sudah terbina selama ini agar terus ditingkatkan dan memperluas hubungan kerjasama dengan pihak lain terkait pendistribusian produk. Kerjasama yang dapat dilakukan misalnya bekerjasama dengan pihak hotel atau tempat wisata terkait pupuk organik untuk kebun maupun pertamanan. UD Darma Puri Farm juga dapat menjual produknya setiap ada kegiatan pameran pertanian.

3. Memperbaiki dan meningkatkan strategi promosi dengan memanfaatkan teknologi informasi yang semakin maju.

Dengan memperbaiki dan meningkatkan strategi promosi yang selama ini dapat dilakukan dengan membagikan brosur, pemberian kartu nama dan memasang spanduk mungkin selanjutnya dapat dilakukan dengan promosi lewat pameran festival agribisnis dan pameran pertanian lainnya dengan memberikan hadiah pamflet mengenai cara pemupukan tanaman yang benar. Memperkenalkan produk kepada masyarakat dengan membuatkan demplot atau memamerkan hasil tanaman dengan menggunakan pupuk atau produk sendiri secara langsung maka diharapkan konsumen akan tertarik untuk mencoba produk tersebut.

4. Memperluas pangsa pasar.

Memperluas pangsa pasar bisa dikatakan memperbesar bisnis usaha. Hal ini dikarenakan jika pangsa pasar meningkat, maka tentu permintaan akan meningkat, kemudian jumlah produk yang dihasilkan juga harus meningkat, termasuk juga tenaga produksi akan meningkat. Dengan melebarkan pasar ke daerah baru diharapkan kedepannya mampu mendapatkan pelanggan baru yang lebih potensial.

\section{Penetapan Strategi Prioritas}

\section{Analisis Matriks SPACE}

Matriks SPACE (Strategic Position and Action), mengindikasikan apakah strategi yang agresif, konservatif, defensif, atau kompetitif yang paling cocok dengan perusahaan tertentu. Sumbu untuk Matriks SPACE mewakili dua dimensi internal, yaitu kekuatan keuangan (financial strength - FS) dan keunggulan kompetitif (competitive advantage CA) dan dua dimensi eksternal, yaitu stabilitas lingkungan (environmental stability - ES) dan kekuatan industri (industrial strength - IS). Keempat faktor ini adalah penentu yang paling penting dari keseluruhan posisi strategis perusahaan. Berdasarkan situasi perusahaan maka Matriks SPACE dapat disajikan pada Tabel 4.

Tabel 4. Matriks SPACE UD Darma Puri Farm

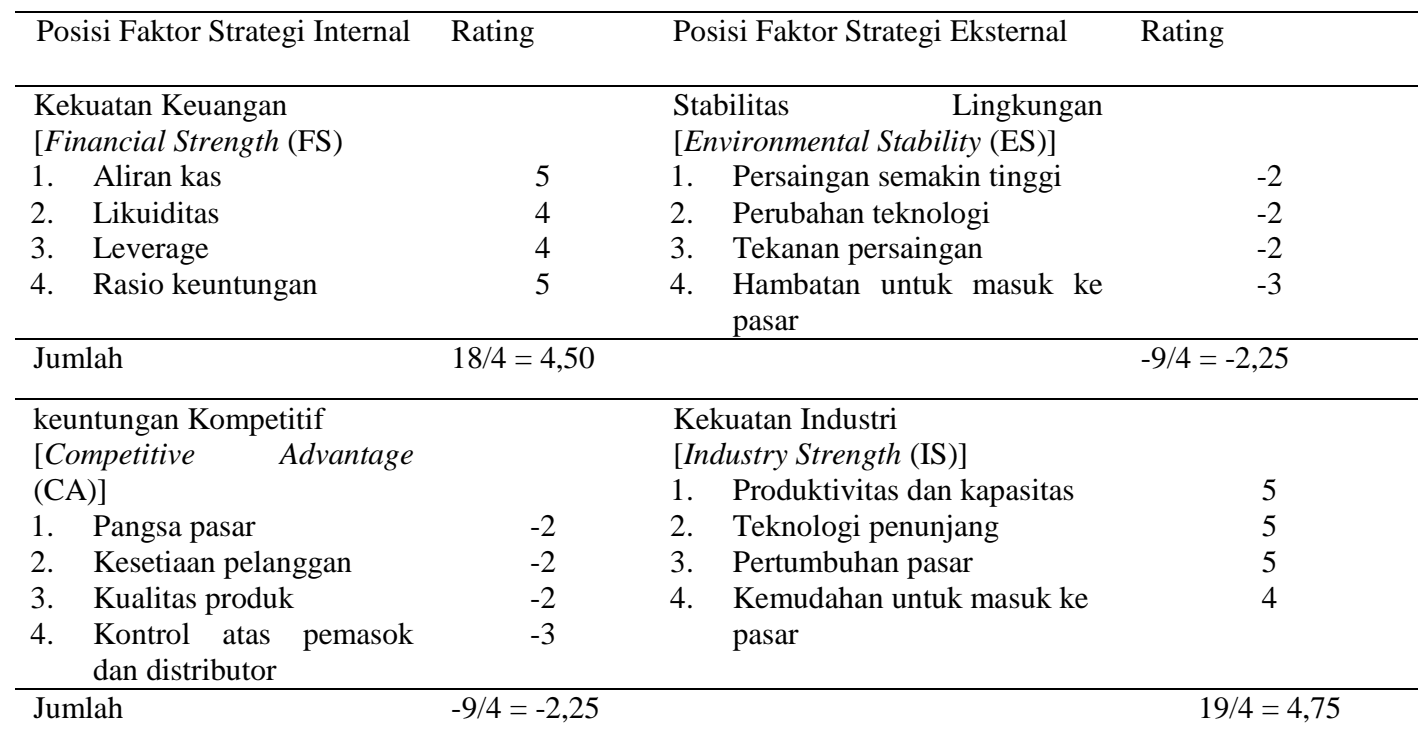

Sumber : Analisis Data Primer Hasil Penelitian (2017)

Rating rata-rata sebagai berikut :

FS + ES atau vektor arah $\mathrm{Y}=4,50+(-2,25)=2.25$

IS + CA atau vector arah $\mathrm{X}=4,75+(-2,25)=2.50$
Setelah ditentukan rating rata-rata untuk sumbu Y dan sumbu X, selanjutnya akan dilakukan pemetaan matriks SPACE sebagai berikut : 


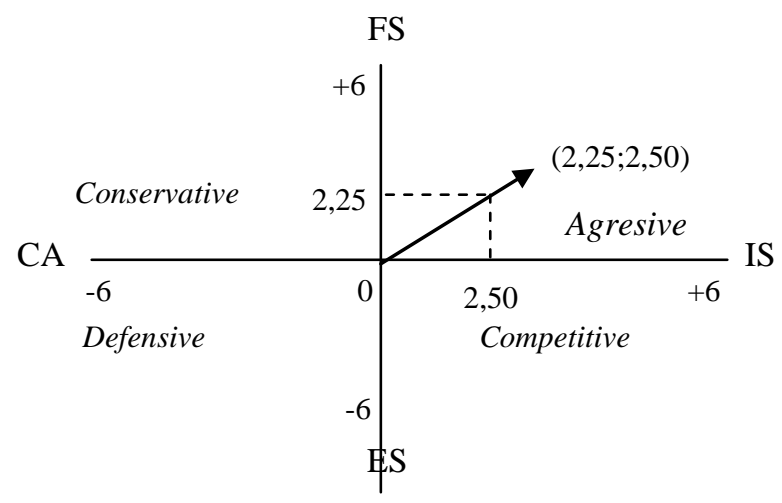

Gambar 3. Diagram Cartesius untuk Matriks SPACE UD Darma Puri Farm

Dari hasil pemetaan matrik space dihasilkan sumbu vertikal dengan nilai 2,25 , sedangkan sumbu horisontal dengan nilai 2,50, maka UD Darma Puri Farm menghasilkan strategi yang positif dan agresif sehingga dapat mendayagunakan secara optimal keuntungan kompetitifnya, dengan cara melaksanakan tindakan yang cukup agresif untuk merebut pasar.

\section{Analisis QSPM (Quantitative Strategic Planning Matrix)}

Berdasarkan matriks SWOT dan matriks SPACE yang dihasilkan strategi alternatif yang sama yaitu strategi agresif yang mencakup strategi intensif, integrasi dan diversifikasi yang nantinya akan dianalisis lebih lanjut menggunkan analisis QSPM.
Analisis QSPM bertujuan untuk menetapkan ketertarikan relatif (Relative Attractiveness Score) dan dari ketiga strategi yang telah dipilih maka ditentukan strategi mana yang paling relevan untuk diimplementasikan Perhitungan matriks QSPM yaitu perkalian antara rata-rata bobot faktor-faktor strategis internal dan eksternal dengan nilai daya tarik (AS) dapat dilihat pada Tabel 6.5 di bawah ini.

Berdasarkan Tabel 5, menunjukkan bahwa prioritas pilihan strategi utama yang harus dilakukan oleh UD Darma Puri Farm adalah memperluas pangsa pasar dengan total nilai kemenarikan paling tinggi yaitu 7,15. Dengan memperluas pangsa pasar diharapkan dapat merambah pasar baru ke daerahdaerah lain yang belum dijangkau perusahaan pesaing untuk memperluas jangkauan yang sudah dimiliki sehingga tujuan perusahaan dapat tercapai. 
Tabel 5. Matriks Perencanaan Strategi Kuantitatif (QSPM)

\begin{tabular}{|c|c|c|c|c|c|c|c|c|c|c|}
\hline \multirow{3}{*}{$\mathrm{N}_{0}$} & \multirow{3}{*}{ Faktor Strategis } & \multirow{3}{*}{ Bobot } & \multicolumn{8}{|c|}{ Alternatif Strategi } \\
\hline & & & \multicolumn{2}{|c|}{ Strategi l } & \multicolumn{2}{|c|}{ Strategi 2} & \multicolumn{2}{|c|}{ Strategi 3} & \multicolumn{2}{|c|}{ Strategi 4} \\
\hline & & & AS & TAS & AS & TAS & AS & TAS & AS & TAS \\
\hline \multicolumn{11}{|c|}{ Kekuatan (Strengths) } \\
\hline 1 & Kualitas produk yang baik & 0.15 & 4 & 0.6 & 4 & 0.6 & 4 & 0.6 & 4 & 0.6 \\
\hline & Lokasi perusahaan strategis & 0.1 & 3 & 0.3 & 3 & 0.3 & 3 & 0.3 & 4 & 0.4 \\
\hline 3 & Harga terjangkau sesuai dengan kualitas produk & 0.1 & 4 & 0.4 & 4 & 0.4 & 4 & 0.4 & 4 & 0.4 \\
\hline 4 & Sarana dan prasarana memadai & 0.1 & 3 & 0.3 & 3 & 0.3 & 2 & 0.2 & 3 & 0.3 \\
\hline 5 & $\begin{array}{l}\text { Intensiffyya pembinaan kelompok-kelompok ternak } \\
\text { melahui dinas terkait }\end{array}$ & 0.1 & 3 & 0.3 & 3 & 0.3 & 3 & 0.3 & 3 & 0.3 \\
\hline \multicolumn{11}{|c|}{ Kelemahan (Weaknesses) } \\
\hline 6 & Jaringan pemasaran masih terbatas & 0.1 & 3 & 0.3 & 4 & 0.4 & 3 & 0.3 & 4 & 0.4 \\
\hline & Proses pengolahan bahan baku yang lambat & 0.1 & 3 & 0.3 & 3 & 0.3 & 3 & 0.3 & 4 & 0.4 \\
\hline & Kegiatan promosi kurang & 0.1 & 4 & 0.4 & 4 & 0.4 & 4 & 0.4 & 4 & 0.4 \\
\hline & Rendahnya pengetahuan SDM & 0.05 & 3 & 0.15 & 3 & 0.15 & 3 & 0.15 & 3 & 0.15 \\
\hline & Persediaan bahan baku yang tidak menentu & 0.1 & 3 & 0.3 & 3 & 0.3 & 3 & 0.3 & 3 & 0.3 \\
\hline \multicolumn{11}{|c|}{ Peluang (Opportunities) } \\
\hline & Daya beli konsumen meningkat & 0.15 & 4 & 0.6 & 4 & 0.6 & 4 & 0.6 & 4 & 0.6 \\
\hline & Pola berfikir masyarakat (konsumen) semakin maju & 0.1 & 4 & 0.4 & 3 & 0.3 & 3 & 0.3 & 3 & 0.3 \\
\hline & Perkembangan teknologi komunikasi mendukung & 0.1 & 3 & 0.3 & 4 & 0.4 & 4 & 0.4 & 3 & 0.3 \\
\hline & Trend Gaya Hidup Sehat & 0.1 & 3 & 0.3 & 3 & 0.3 & 3 & 0.3 & 4 & 0.4 \\
\hline & $\begin{array}{l}\text { Persepsi konsumen terhadap merek tinggi } \\
\text { Ancaman (Threats) }\end{array}$ & 0.1 & 3 & 0.3 & 3 & 0.3 & 3 & 0.3 & 3 & 0.3 \\
\hline & Perusahaan pesaing & 0.1 & 3 & 0.3 & 4 & 0.4 & 4 & 0.4 & 4 & 0.4 \\
\hline & Naiknya biaya produksi & 0.1 & 3 & 0.3 & 3 & 0.3 & 3 & 0.3 & 4 & 0.4 \\
\hline & Ketersediaan tenaga kerja sedikit & 0.1 & 3 & 0.3 & 3 & 0.3 & 3 & 0.3 & 3 & 0.3 \\
\hline & Faktor cuaca yang tidak menentu & 0.05 & 3 & 0.15 & 3 & 0.15 & 3 & 0.15 & 4 & 0.2 \\
\hline & Posisi tawar konsumen semakin tinggi & 0.1 & 3 & 0.3 & 3 & 0.3 & 3 & 0.3 & 3 & 0.3 \\
\hline & Total & & & 6.6 & & 6.8 & & 6.6 & & 7.15 \\
\hline
\end{tabular}

\section{SIMPULAN DAN SARAN}

\section{Simpulan}

Berdasarkan hasil analisis dan pembahasan yang telah dilakukan dalam penelitian ini, maka dapat diperoleh simpulan sebagai berikut.

1. Berdasarkan analisis matriks SWOT didapatkan empat alternatif strategi dengan urutan prioritas yaitu (1). Berusaha mempertahankan dan meningkatkan kualitas pupuk organik. (2). Mempertahankan mitra yang lama dan menjajaki kemitraan yang baru. (3). Memperbaiki dan meningkatkan strategi promosi dengan memanfaatkan teknologi informasi yang semakin maju. (4). Memperluas pangsa pasar.

2. Berdasarkan Matriks QSPM, diperoleh strategi pemasaran yang relevan untuk diterapkan oleh UD Darma Puri Farm adalah memperluas pangsa pasar yang menjadi pilihan pertama diantara keempat strategi lainnya.

\section{Saran}

Berdasarkan hasil penelitian ini, dapat disarankan beberapa hal kepada perusahaan ataupun peneliti selanjutnya yaitu :

1. Dengan memanfaatkan media dan strategi online marketing yang baik, maka diharapkan dapat meningkatkan penjualan tanpa batasan ruang dan waktu. Selain itu, peningkatan SEO (Search Engine Optimization) juga diperlukan untuk memudahkan pelanggan dunia maya menemukan produk pupuk organik yang akan dipasarkan.

2. Agar usaha dapat berkembang, maka yang harus dilakukan yaitu peningkatan alat produksi, efisiensi, dan produktivitas melalui sistem kerja yang ditujukan untuk memperbaiki proses produksi, serta meningkatkan kualitas SDM pada tenaga kerja yakni melalui pendidikan dan pelatihan.

3. Untuk Mengembangkan usaha maka diperlukan dukungan dari keseluruhan elemen, tidak hanya dari sisi internal pelaku usaha saja tetapi juga diperlukan peran pemerintah dalam mendukung Ni Made Yuni Erawati, et al., Strategi..|80 
pengembangan usaha. Maka diharapkan pemerintah dapat memberikan dukungannya dengan memberikan pendidikan kewirausahaan kepada pelaku usaha melalui bimbingan dan penyuluhan untuk meningkatkan kemampuan usaha kecil agar menjadi usaha yang tangguh dan mandiri, serta memberikan bantuan modal usaha untuk meningkatkan keinginan pelaku usaha mengembangkan usahanya.

4. Penelitian ini masih memiliki berbagai kelemahan dan kekurangan, oleh karenanya dipandang perlu dilakukan penelitian lebih lanjut dan lebih komprehensif.

\section{UCAPAN TERIMA KASIH}

Pada kesempatan ini perkenankanlah penulis mengucapkan terimakasih yang tulus kepada Rektor Universitas Udayana Ibu Prof. Dr. dr. A.A. Raka Sudewi, Sp.S.(K), Dekan Fakultas Pertanian Universitas Udayana Prof. Dr. Ir. I Nyoman Rai, MS, dan Ketua Program Studi Magister Agribisnis Universitas Udayana Dr. I Wayan Budiasa, SP,.MP atas kesempatan dan fasilitas yang diberikan kepada penulis untuk mengikuti dan menyelesaikan pendidikan Program Magister di Universitas Udayana.

Terimakasih juga penulis ucapkan kepada Bapak Dr. Ir Ketut Suamba, MP selaku pembimbing I dan Ibu Dr. Ir. Ni Wayan Sri Astiti, MP selaku pembimbing II yang dengan penuh perhatian dan kesabaran telah memberikan dorongan, semangat, bimbingan dan saran selama penulisan ini. Serta tidak lupa juga penulis mengucapkan terima kasih kepada Prof. Dr. Ir Dwi Putra Darmawan, MP, Prof. Dr. Ir. Ketut Budi Susrusa, MS dan Dr. Ir. I Dewa Putu Oka Suardi, M.Si selaku dosen penguji yang juga telah meluangkan waktunya serta memberikan saran demi perbaikan Tesis ini.

Terimakasih yang sebesar-besarnya dilanjutkan kepada Bapak I Ketut Darmawan, S.Pt selaku pemilik UD Darma Puri Farm, yang telah memberikan ijin penelitian serta memberikan data terkait keperluan penelitian ini. Kepada Kepala Dinas Tanaman Pangan, Hortikultura dan Perkebunan dan Kepala UPT. Pertanian Terintegrasi Dinas Tanaman Pangan, Hortikultura dan Perkebunan yang telah memberikan data sekunder sebagai penunjang data penelitian, serta seluruh stakeholders yang membantu memberikan informasi terkait penelitian ini.

\section{DAFTAR PUSTAKA}

Alley, M. dan W.G. Wysor. 2005. Fertilizer in 2005. Crop and Soil Environment News, February 2005

Antara, M. 2010. Bahan Ajar Metode Penelitian Sosial Ekonomi. Denpasar : Universitas Udayana.
Christensen, L.B. 2004. Experimental Methodology, $9^{\text {th }}$ ed. Boston. Pearson.

Darmono. Faniwiryojo dan Isroi. 2008. Pupuk Cair. Balai Penelitian Bioteknologi Perkebunan Indonesia (BPBPI) Seminar Nasional dan Temu Bisnis Pupuk untuk Perkebunan. Surabaya.

David, Fred R. 2004. Manajemen Strategi. PT. Naragita Dinamika, Jakarta.

David, Fred R. 2009. Manajemen Strategis Konsep, Edisi 12. Jakarta : Salemba Empat

Dinas Pertanian Tanaman Pangan Provinsi Bali. 2013. Laporan Subsidi Pupuk Organik Provinsi Bali.

Indriyo Gitosudarmo. 2008. Manajemen Pemasaran. Edisi kedua, Yogyakarta : BPFE - YOGYAKARTA

Kotler, Philip. 2000. Manajemen Pemasaran. Edisi Mileinium. Jakarta : PT. Indeks Kelompok Gramedia.

Lingga dan Marsono. 2002. Petunjuk Penggunaan Pupuk. Penebar Swadaya. Jakarta

Lingga dan Marsono. 2013. Petunjuk Penggunaan Pupuk. Penebar Swadaya. Jakarta

Musnamar, E. I., 2009. Pupuk Organik : Cair dan Padat, Pembuatan, Aplikasi. Penebar Swadaya. Jakarta

Nugroho, P. 2012. Panduan Membuat Pupuk Kompos Cair. Penerbit Pustaka Baru Press. Yogyakarta.

Noor, J. .2011. Metodelogi Penelitian. Jakarta : Kencana

Novizan. 2002. Petunjuk Pemupukan yang Efektif. Agromedia. Jakarta

Pirngadi K dan Makarim AK. 2006. Pengelolaan Tanaman Terpadu Lahan Sawah Tadah Hujan. Penelitian Pertanian Tanaman Pangan 25 (2) : 116-123

Rangkuti, Freddy. 2002. Analisis SWOT Teknik Membedah Kasus Bisnis. Jakarta : PT. Gramedia Pustaka Tama.

Rangkuti, Freddy. 2004. Analisis SWOT Teknik Membedah Kasus Bisnis. Jakarta : PT. Gramedia Pustaka Tama.

Rangkuti, Freddy. 2008. Analisis SWOT Teknik Membedah Kasus Bisnis. Jakarta: PT Gramedia Pustaka Utama.

Sugiyono. 2014. Metode Penelitian Kuantitatif, Kualitatif, dan Kombinasi (Mixed Methods). Bandung : Alfabeta

Ni Made Yuni Erawati, et al., Strategi..|81 
Sutanto R. 2002. Penerapan Pertanian Organik. Pemasyarakatan dan Pengembangannya. Yogyakarta : Kanisius

Sutanto R. 2002. Pertanian Organik. Мепијu Alternatif dan Berkelanjutan. Yogyakarta : Kansisius Husein U. 2003. Studi Kelayakan Bisnis.
Sutedjo, M. M. 1992. Pupuk dan Cara Pemupukan. Rineka Cipta. Jakarta

Suwarsono, Muhammad, 2002. Manajemen Strategik ; Konsep dan kasus, Edisi ketiga, UPP AMP YKPN, Yogyakarta

Umar, H. 2003. Strategic Management in Action. Jakarta : PT. Gramedia Pustaka Utama

4.5

4.6 